\title{
Making Communism Work: Sinicizing a Soviet Governance Practice
}

\section{Citation}

Perry, Elizabeth. 2019. Making Communism Work: Sinicizing a Soviet Governance Practice.

Comparative Studies in Society and History 61 (3).

\section{Permanent link}

http://nrs.harvard.edu/urn-3:HUL.InstRepos:38558100

\section{Terms of Use}

This article was downloaded from Harvard University's DASH repository, and is made available under the terms and conditions applicable to Open Access Policy Articles, as set forth at http:// nrs.harvard.edu/urn-3:HUL.InstRepos:dash.current.terms-of-use\#OAP

\section{Share Your Story}

The Harvard community has made this article openly available.

Please share how this access benefits you. Submit a story.

\section{Accessibility}




\title{
Making Communism Work: Sinicizing a Soviet
}

\section{Governance Practice}

\author{
ELIZABETH J. PERRY \\ Department of Government, Harvard University, Director, Harvard-Yenching Institute
}

\section{GOVERNING THE GRASSROOTS}

Governing any large society, whether in modern or premodern times, requires effective channels for connecting center and periphery. With government officials and their coercive forces concentrated in the capital, the central state's capacity to communicate and implement its policies at lower levels is not a given. Reaching the grassroots is, however, crucial for regime effectiveness and durability. Regardless of regime type, the official bureaucracy serves as the primary conduit for routine state-society communication and compliance, but it is subject to capture by its own interests and agenda. Extra-bureaucratic mechanisms that provide a more direct linkage between ruler and ruled therefore prove critical to the operation and endurance of democracies and dictatorships alike.

Imperial China (221 BC-1911 AD), the longest-lived political system in world history, devised various means of central-local connectivity. The most famous was the highly competitive civil service examination for recruiting members of society into the government bureaucracy. ${ }^{1}$ But extra-bureaucratic channels were also important. For example, a periodic program of state-appointed lecturers known as "rural compacts" (乡约) conveyed instructions to villagers based on imperial edicts from the capital. Originally introduced as a form of ideological indoctrination, the system over time became invested with additional critical responsibilities such 
as surveillance and defense. ${ }^{2}$ Other extra-bureaucratic forms of governance, which served as a counterweight and check on the operations of the imperial administration, included the deployment of Censors and Commissioners. ${ }^{3}$ In Republican China (1912-1949), despite advances in communications technology, the challenge of governing grassroots society persisted. The failure of the short-lived Kuomintang regime (1927-1949) to consolidate a strong state is attributed, among other things, to its inability to span the yawning central-local abyss. ${ }^{4}$

The difficulty of cultivating and controlling a dispersed and diverse grassroots constituency also bedeviled the Chinese Communist Party (CCP) from its earliest days. Founded in 1921 by urban intellectuals, the new party (in line with Marxism's focus on the industrial proletariat as well as the recent example of the Russian Revolution) initially concentrated its organizing energy on factory workers in major industrial centers. ${ }^{5}$ Although astute CCP activists like Peng Pai and Mao Zedong recognized the potential power of the Chinese peasantry, they could glean little guidance from the Soviet experience on how best to organize them. The social base of the Bolshevik Revolution had been confined largely to the workers of Moscow and St. Petersburg, while subsequent attempts to impose Soviet power in the countryside proved tragically oppressive, provoking bitter resentment and widespread resistance from Russian peasants. ${ }^{6}$ The CCP would need to develop an alternative approach, better attuned to local concerns, if it were to succeed at the pressing task of grassroots mobilization.

Of the many ways in which Chinese Communism departed from Soviet Communism, perhaps the most significant was the former's much closer ties to the countryside. ${ }^{7}$ From the revolutionary period to the present, multiple conduits have connected CCP cadres to townships and villages far removed from major cities. Among these various linkages, arguably none has proven more critical for effective grassroots mobilization and governance than the practice of 
deploying “work teams” (工作队/工作组/工作团). Yet, perhaps because work teams straddle the boundary between informal and formal institutions (absent from official organization charts and active for only an interim period, yet authorized and operated by official agencies), they have received scant analytical attention from students of Chinese history and politics. While work teams figure prominently in narrative accounts of the major campaigns of the PRC, their origins, operations and political implications have yet to be fully explored.

Work teams are ad hoc units that are appointed and directed by higher-level Party and government organs to advance a specific mission, dispatched to the grassroots for a limited period to carry out their assignment by means of mass mobilization. Work teams were central to the implementation of Land Reform during the Civil War and early PRC periods, and to a host of subsequent CCP-sponsored campaigns and state responses to unexpected crises. At times work teams convey a broad, nationwide mandate for change, with tens of thousands of them operating simultaneously across the country. At other times their mission is narrowly circumscribed by task and locale, and their number may even be limited to a single team. The practice of deploying work teams in order to promote developmental priorities, troubleshoot crises, propagate ideology, and monitor and discipline local cadres, among other purposes, remains one of the most common and effective methods of Chinese Communist Party governance even today. ${ }^{8}$ This paper examines the origins and evolution of work teams (from the 1920s until the mid-1960s) in an effort to understand how the Chinese Communist Party fashioned this functional and flexible mode of central-local connectivity.

The roots of Chinese work teams were planted deep in Russian revolutionary soil, but the successful flowering of this practice was due to creative CCP cultivation over decades of revolutionary and post-revolutionary transplantation and experimentation. Mao and his comrades 
deserve credit for converting the Bolsheviks' campaign method of dispatching mobile units (e.g., grain detachments, 25,000ers, shock brigades, and so on) into a distinctively Chinese mode of governance. Sinicized work teams were not only a key factor in the victory of the Chinese Communist revolution; they have continued to play a critical role in the development and control of the vast Chinese hinterland - right down to the contemporary poverty alleviation and anticorruption campaigns. As an effective means of spanning the central-local divide, work teams contribute powerfully to the resilience of the Chinese Communist party-state.

\section{REVOLUTIONARY ORIGINS}

The genesis of Chinese work teams can be traced at least as far back as the early 1920s, when the $\mathrm{CCP}$ - under the aegis of a United Front with the Kuomintang (KMT) and under the guidance of Soviet advisors-first began to craft a systematic strategy for grassroots mobilization. At the Peasant Movement Training Institute (PMTI) in Guangzhou, established in the summer of 1923 as an official KMT entity reporting to its Peasant Bureau, Communist organizers Peng Pai and Mao Zedong instructed and assigned aspiring young revolutionaries in a manner that anticipated the later formation of work teams. Trainees at the Institute were drawn largely from the ranks of politically engaged high school and college students. After receiving several months of intensive classroom and in-field training followed by rudimentary military instruction, a certain number of outstanding PMTI graduates would be sent to the countryside as "special commissioners" (特派 员) whose mission was to rouse the peasants to revolutionary action. The first five classes of the PMTI graduated a total of 454 trainees, of whom one-third were chosen as special commissioners. Their selection was based in part on their training program grades and in part on the recommendation of the “Inspection Committee” (检查委员会) of the PMTI, which was responsible for monitoring all aspects of student behavior. While most graduates returned home 
to their own native places, those designated as commissioners were dispatched to villages that the Peasant Bureau determined to be in special need of their services. ${ }^{9}$

Special commissioners prefigured the later practice of work teams in several respects: commissioners were appointed by an official agency (the KMT's Peasant Bureau) to carry out a focused mass mobilization effort within a limited period of intensive engagement. Commissioners differed from work teams, however, in that they were deployed as single individuals rather than in groups. They were expected to spend at least six hours a day in their assigned locales, conducting investigations and undertaking propaganda and organization work. Commissioners were also required to submit weekly reports to the Peasant Bureau and to return to the bureau's headquarters in Guangzhou after each operation to await instructions for their next assignment. ${ }^{10}$

The use of special commissioners was reminiscent of the venerable Chinese practice of “Imperial Commissioners” (钦差大臣), trusted officials whom the emperor would deputize to handle a pressing matter in the provinces by exercising ad hoc plenipotentiary powers that trumped those of the regular bureaucracy. Commissioner Lin Zexu's suppression of the opium trade as a special emissary of the Daoguang Emperor in 1839 was an iconic instance. ${ }^{11}$ Despite such indigenous antecedents, the lineage of the 1920s special commissioners trained at the PMTI is more directly attributable to Russian than to Chinese ancestry. The Guangzhou Peasant Movement Training Institute had been founded on the advice of Mikhail Borodin and his fellow "sovetniki" (Soviet agents in China) who also lectured at the Institute on Russian revolutionary techniques of agitation and propaganda. ${ }^{12}$

Among the most important Bolshevik agitprop methods in use at the time were so-called "plenipotentiaries" and "emissaries" who had played a key mobilizing role in the October 
Revolution of 1917 and the Civil War that followed in its wake. The practice had been anticipated by the tsarist tradition of itinerant inspectors, memorialized in 1836 in Nikolai Gogol's famous satirical drama, The Government Inspector. ${ }^{13}$ But the Bolsheviks did not point to Russian history to explain their reliance on such individuals. In the lead up to the 1917 Revolution, Lenin justified the Bolsheviks' use of plenipotentiaries on grounds that during the French Revolution centrally-appointed emissaries (known as representants en mission or "representatives on mission") deserved credit for turning around an otherwise faltering effort. ${ }^{14}$ Under Stalin's rule, the deployment of envoys to the grassroots was significantly expanded. In the 1920s and 1930s, the Soviet Union relied on plenipotentiaries - augmented by Komsomol brigades, 25,000 ers, shock brigades, troikas and other ad hoc mobile units - to carry out a brutal campaign of collectivization and dekulakization in the countryside.

During the early days of the Chinese Communist revolution, the Russian concept of “plenipotentiary” was generally translated into Chinese as quanquan daibiao (全权代表), or fully empowered emissary, but soon the more common Chinese rendering was tepaiyuan (特派 员). It is possible that the term tepaiyuan, which held the dual meanings of "special correspondent" and "special commissioner," gained currency due to the fact that many of the early Comintern agents, including Grigori Voitinsky and Mikhail Borodin, were sent to China under the guise of newspaper correspondents. In Chinese accounts of his activities, Voitinsky is referred to variously as a “plenipotentiary” (全权代表) or “special commissioner” (特派员), appointed by the Far Eastern branch of the Comintern, who in March 1920 led a small "work team” (工作组) of Comintern agents to China for the purpose of organizing a Chinese Communist Party. ${ }^{15}$ Similarly, Borodin's public persona in Guangzhou was as a "special correspondent/commissioner” (特派员) for the Russian news agency Tass, while his real 
assignment was as a “permanent plenipotentiary" (永久的全权代表) to Sun Yat-sen. ${ }^{16}$ After the Chinese Communist Party was founded, the terms were used interchangeably to refer to Chinese operatives who reported to the CCP, as well as to Russians and other foreigners working in China on assignment from the Comintern. During the period of the First United Front to combat warlordism in China, the special commissioners operated under the formal auspices of the KMT, but a report of the CCP's Guangdong District Committee in June 1926 claimed that "some 99 percent of the special commissioners of the KMT Peasant Bureau are our own comrades."17 Despite being officially commissioned by the KMT, the tepaiyuan were in reality Communist agents.

Historian Wang Qisheng has ascribed the origins of work teams to the Chinese Communists' deployment of special commissioners from the Peasant Movement Training Institute before and during the Northern Expedition. As Wang explains, "the mechanism of tepaiyuan initially was a mechanism for mass mobilization in the period before the CCP held political power. In the many mass campaigns of the wartime and post-' 49 periods, this [mechanism] was inherited and greatly expanded in the form of work teams. ${ }^{, 18}$ Wang, however, does not connect this practice to Soviet precedents, nor does he trace the process by which the special commissioners of the $1920 \mathrm{~s}$ evolved into the work teams of the 1930s and later.

Although tepaiyuan, like Bolshevik plenipotentiaries, were deputized as individuals, as early as the mid-1920s the CCP had also begun to utilize various kinds of small-scale groups for purposes of disseminating propaganda and inciting revolutionary action among the peasantry. ${ }^{19}$ This, too, was surely prompted by Soviet precedents. In the Russian Revolution and its aftermath, mobile units (sometimes operating out of trains and boats and equipped with printing presses and movie projectors) were widely deployed for purposes of agitprop. ${ }^{20}$ In the Chinese 
case, as part of their instruction at the Peasant Movement Training Institute, trainees were sent down to nearby villages in “small teams” (小队) of four people each, charged with carrying out rural investigations and disseminating propaganda as a prelude to setting up peasant associations. $^{21}$ The peasant associations themselves were evidently modeled on the short-lived Kombedy, or Committees of the Village Poor, that had been established in the Soviet Union by the new Bolshevik government for purposes of grain expropriation and redistribution in $1918 .^{22}$ Similar efforts to dispatch small groups of activists to the countryside were underway in other places as well. In the winter of 1923, for example, CCP member Dong Biwu organized a dozen university and high school students from his own native county of Hong'an studying in the city of Wuhan into a Party and Youth League "work team" (工作组) that returned to the countryside to carry out mass education. ${ }^{23}$

Shortly before the closure of the Peasant Movement Training Institute in 1926, the CCP issued a Resolution on the Peasant Movement summarizing the insights it had gleaned over the previous several years of organizing among Guangdong villagers. Topping the list of lessons learned was the importance of getting close to the people by adopting local customs: "Those working in the peasant movement must first do as the peasants do in speech and action. Their living conditions and clothing must also be similar to that of the peasants." ${ }^{24}$ Important as it was to embrace rural folkways, the $\mathrm{CCP}$ recognized the special resources that intellectuals and urbanites could bring to the revolutionary enterprise. At the same time that Communist cadres were enjoined to blend in with ordinary peasants, they were advised to recruit those with greater education and urban ties: "Use should be made of village primary school teachers, comrades and city workers who are natives of villages, and students returning to the villages for holidays, to initiate organizational work. Primary school teachers in particular are the natural leaders of the 
villages. We should earnestly enlist this group in our ranks. ${ }^{, 25}$ The call to recruit sympathetic students and teachers who could appreciate the value of indigenous customs would remain a key feature of Chinese work team operations in the years ahead. In time it would become clear that the CCP's goal was to edify the team members themselves as much as to connect them with their intended constituency. This interest in producing "organic intellectuals," to borrow Gramsci's term, heralded a significant departure from the Russian prototype. ${ }^{26}$

More systematic development of work teams as a mode of mass mobilization accompanied the formation of the Red Army. In November of 1927, Mao Zedong (who several months earlier had been appointed by Party Central as a tepaiyuan in command of the Autumn Harvest Uprising along the Hunan-Jiangxi border) summed up the three main responsibilities of the Communists' new armed force: combat, requisition, and mass work - of which the third was deemed most important. ${ }^{27}$ In January 1928, the Red Army arranged for its maiden propaganda teams to carry out grassroots mobilization; such teams "would prove a permanent part of Red Army organization. ${ }^{, 28}$ At the Gutian conference in December 1929, Mao's own report stressed the political work of the Red Army, emphasizing the need for the military to disseminate revolutionary propaganda among the rural masses through drama troupes and other means. ${ }^{29}$

With the founding of the Jiangxi Soviet in 1931, the CCP's use of various kinds of mobile teams expanded beyond the realm of military cultural propaganda to encompass a wider range of mobilization and governance purposes. Soon after the new Chinese Soviet government was established in Ruijin, a system of “Inspectors" (巡视员) was adopted in accord with Bolshevik practice at the time. Regulations issued in 1931-1932 stipulated that Inspectors must have been CCP members for at least three years and to have held local party positions. Their mission was to serve as the eyes, ears and arms of Party Central: "As Inspectors, they are plenipotentiaries of 
the Center who check up on and supervise work among all local Party branches” (巡视员是中央 对各地党部考查和指导工作的全权代表). Before setting out on assignment, Inspectors, whether working alone or in a small group, needed to have a detailed plan of action approved by Party Central. While in the field, they were required to keep a daily diary and to report back to Central at least bi-weekly. ${ }^{30}$ Often referred to as tepaiyuan, the Inspectors-cum-plenipotentiariescum-Special Commissioners were granted sweeping, but not unlimited, powers on the ground; for example, they were allowed to make arrests only after obtaining higher-level authorization, except under unusual circumstances as in case of counter-revolutionary elements believed to be plotting imminent uprisings or poised to take flight. ${ }^{31}$

The Jiangxi Soviet also introduced a Worker-Peasant Procuratorate (工农检察部), under the direction of the Central Committee, with responsibility to monitor state enterprises and agencies within the Soviet area and to report incidents of bribery, embezzlement, waste and other crimes to the courts. The system was obviously patterned on the Rabkrin, or Workers' and Peasants' Inspectorate, then in place in the Soviet Union. ${ }^{32}$ Under the Procuratorate was a Bureau of Control and Complaints (控告局) which organized shock brigades (突击队) of ordinary citizens who conducted unannounced inspections of state agencies and enterprises. ${ }^{33}$ Cadres in the Bureau were recruited from reliable peasants and agricultural laborers who, after receiving special training, were sent back to the countryside to gather complaints about local officials from villagers. ${ }^{34}$ Shock brigades, whose composition changed with each deployment, operated with a minimum of three members who carried out their assignment in their spare time. Before disbanding, the group was required to submit a written report to the party or government agency which had dispatched it. ${ }^{35}$ As political scientist Ilpyong Kim explains, this system was "a special mechanism through which the party and the central government attempted to exercise political 
control over the conduct of the government officials working at the local level. ${ }^{.36}$ The Bureau of Control and Complaints was responsible for installing grievance boxes in locations where workers and peasants resided in concentrated numbers, encouraging them to register complaints against official malfeasance. Shock brigades were then dispatched without warning to investigate such allegations, serving as an important check on waste and corruption among personnel in state economic agencies. ${ }^{37}$

In 1933 (on the eve of the Rabkrin's dissolution in the USSR), ${ }^{38}$ the functions of the Worker-Peasant Procuratorate increased dramatically when the Jiangxi Soviet government launched campaigns for land investigation, cooperatives, and economic reconstruction. In conjunction with these campaigns, central authorities in Ruijin dispatched "work teams" (referred to variously as 工作团 or 工作组) to districts under their control to investigate corruption and incite mass struggle..$^{39}$ In the summer of 1933, Mao Zedong commented approvingly on the deployment of a central work team in Rentian District, crediting the team with a range of "revolutionary" accomplishments: "During a period of fifty-five days, the Land Investigation Movement in Rentian District, with the help of a Central Government Work Team (中央政府工作团), roused the masses of the entire district to action; radically destroyed the feudal remnants; uncovered more than three hundred households of landlords and rich peasants; shot twelve counterrevolutionary elements, called 'big tigers' by the masses; and suppressed counterrevolutionary activities. ${ }^{, 40} \mathrm{CCP}$ cadres were themselves increasingly subject to work team surveillance. In November 1933 a work team sent by the Central Committee conducted a "shock audit" which uncovered serious corruption in the banqueting practices of officials in the Ruijin County government. ${ }^{41}$

The war against Japan saw a further expansion and diversification in the Chinese 
Communists' deployment of work teams. In August 1937, Party Central issued a document encouraging military units to establish “mass movement work teams" (民运工作组) to enforce discipline and undertake mobilization among local residents. ${ }^{42}$ Two years later, Party Central indicated that women, including both members and non-members of the official women's association, should be organized into wartime "work teams" (工作队) to coordinate activities and attract more activists to the cause. ${ }^{43}$ In areas where Japanese and Kuomintang military incursions posed a threat, the CCP established “armed work teams" (武装工作队 also known as 武工队) composed of both military and political cadres. The armed teams were credited with penetrating deep inside enemy lines to mobilize the masses. ${ }^{44}$ A central directive in the spring of 1945 called for armed work teams to act as "political work teams." They were to be led by experienced government and party cadres capable of implementing policy flexibly under inhospitable conditions. Armed work teams were expected to participate in rural labor alongside villagers in the areas where they were deployed to win local support and protection, lessen the peasants' economic burden, and thereby generally improve mass livelihood. The teams were authorized to use a variety of methods, including covert ones, to establish pro-CCP strongholds (据点) in otherwise hostile territory. ${ }^{45}$ In contrast to guerrilla units, however, armed work teams were not primarily combat forces. Their mandate was not to fight the Japanese or KMT but to inspire and organize the rural populace.

It was during the anti-Japanese war that Chinese Communist work teams began to assume the distinctive form that would persist into the PRC. A prominent aspect of the wartime era was the growing participation of idealistic young intellectuals, often women, in CCP-sponsored rural work teams tasked with implementing a range of progressive economic programs. Historian Chen Yung-fa concludes of the Communist base areas during this period that "the scanty 
information available leads me to suspect that an overwhelming majority of the mass workers were young urban students inspired by patriotism to join the cause. ${ }^{46}$ Even for those motivated by socialist as much as by nationalist ideals, carrying the Communist revolution to the countryside was not an easy assignment for urban intellectuals. Before engaging in such work, prospective team members were put through a rigorous training program in which, in addition to political education, they received instruction on how to dress, eat, talk and live as peasants. ${ }^{47}$

In 1941, work teams operating in Yancheng, Jiangsu set a pattern that would soon be emulated in Communist base areas across Central and North China. The Yancheng model of mass mobilization involved several steps. First was the decision to focus on a handful of townships chosen on the basis of the likelihood of successful mobilization and the potential for maximum political impact and diffusion due to their strategic location. Next a work team of some thirty to forty cadres was sent to a market town with a county government. This team formed a preparatory committee and, in the name of the regional peasant association, posted regulations about economic programs on the wall of the main government office. Four or five team members remained in the office while the rest were dispatched to lower levels. In each township, five or six mass workers concentrated on a single site. They arrived at a village with letters of introduction to the local authorities (保甲长), who were asked to assist in convening meetings and explaining policies. On the first day in a village, the work team members conducted door to door household investigations, recording details of all residents' class backgrounds. The following day they held meetings with various groups of villagers to uncover grievances and identify activists. On the third day, they convened a mass meeting at which resolutions were passed and a peasant association was officially founded. This was followed by a mass rally and a march on selected landlords' houses to demand rent reduction or other 
economic concessions. After a public struggle session against targeted victims, a celebratory parade with festive placards, accompanied by the sound of drums and cymbals, carried news of the event to surrounding communities. The entire process usually took about ten days to complete. $^{48}$

In time, the composition of the work teams became more standardized, with two male members assigned to take charge of investigation and propaganda work, one or two women to handle women's work, and a teenager to focus on organizing the village children. Unlike Soviet precedents of Plenipotentiaries and Workers' and Peasants' Inspectorates, in China young intellectuals were considered especially capable of communicating and clarifying Party policies. The central role of intellectuals, which followed in the tradition of the Guangzhou Peasant Movement Training Institute, was in part a recognition of the special prestige and authority that those with educational credentials had commanded in Chinese society since imperial days. The involvement of young intellectuals reflected another consideration as well, however. The Rectification (整风) launched in Yan'an in 1942, which marked Mao's retreat from Soviet orthodoxy in favor of his own approach to revolution, saw a concerted effort to remold the "bourgeois" mentality of the tens of thousands of idealistic students and teachers who had flocked to the Communist cause. ${ }^{49}$ Assigning such individuals to work teams fulfilled the dual goals of utilizing their skills and social standing to assist the peasantry while at the same time affording intellectuals an opportunity to transform their own elitist outlook by participating in revolutionary struggle alongside the masses. ${ }^{50}$ Although a chief task of the work teams was to plan and stage highly charged struggle sessions against carefully chosen targets, team members were cautioned against being too conspicuous during the struggle meeting itself. ${ }^{51}$ The goal was to present the dramatic conclusion of their efforts as an organic, bottom-up expression of peasant 
class action.

With the defeat of Japan and the outbreak of Civil War between the Communists and the Nationalists that followed in its wake, the CCP developed its techniques of mass mobilization still further. It was in this period that work teams added a powerful new weapon to their struggle repertoire in the form of emotional "speak bitterness" (诉苦) assemblies at which poor peasants and other downtrodden and aggrieved individuals hurled accusations against the landlords and “evil tyrants" (恶霸) who had oppressed them in the past. This cathartic practice was first promoted on a large scale within the People's Liberation Army (PLA) in the summer of 1947 as a means of encouraging recent PLA recruits, many of whom were defectors from Chiang Kaishek's Nationalist Army, to renounce their previous affiliation in favor of conversion to the Communist cause. In some cases, a straw effigy of Chiang would be placed in front of a squadron of newly enlisted PLA soldiers, who shouted out impassioned denunciations of their former commander and then proceeded to curse and beat his likeness to shreds. ${ }^{52}$ When the Communists launched their historic Land Reform Campaign with the help of the PLA later that year, Speak Bitterness assemblies were a signature feature. A major responsibility of Land Reform work teams was to identify and instruct “masters of bitterness" (苦主) among the poorest villagers to take the lead in struggling against local powerholders. The heart-rending tales of suffering at the hands of landlords, rich peasants, and other alleged exploiters, carefully choreographed by the work team for maximum emotional effect on the audience, was designed to evoke a demonstrative response from fellow villagers. In this rendition of Speak Bitterness, live targets replaced straw effigies as the objects of struggle. ${ }^{53}$

Despite increased systematization in both composition and operations, the defining feature of work teams remained their ad hoc, task-specific character. Assignments were temporary, and 
members returned to their previous jobs after completing their mission. While individuals might well be deployed on multiple work teams over the course of their careers, and even during a single campaign, they would do so on each occasion with a different group of colleagues.

\section{Post-Revolutionary DeVElopment}

As the Communist victory in the Civil War loomed on the horizon, Mao Zedong instructed field armies in the liberated areas to shift their focus from combat to occupation and mobilization, calling on the military in a 8 February 1948 telegram to "convert the army into a work team." Some of the squadrons-turned-work teams carried out land reform in villages across the North China Plain; others were sent to Guangzhou, Shanghai, and other major Southern cities as socalled “Southbound work teams" (南下工作队). In both cases, former soldiers were joined by intellectuals, government and party cadres, and grassroots activists. ${ }^{55}$ By July 1949 , counties across the country had established special training centers led by seasoned cadres to provide localized instruction for work teams operating in the area. ${ }^{56}$

In a fashion that resembled Soviet grain brigades during the Russian Civil War and the subsequent collectivization campaign, Chinese work teams at this time, whether engaged in land reform or city takeovers, were expected to oversee the requisitioning and redistribution of food and other materiel for the military. In places where existing local officials could be relied upon, the grain requisition work teams (粮秣工作队) worked through them, but elsewhere the teams themselves collected grain and other supplies and transferred them to the occupying forces as needed. In either case, the work teams were required to keep detailed accounts of all such transactions, open at any time to inspection by political and military officials. ${ }^{57}$

As in the wartime era, the composition and training of work teams received particular attention. Many members of grain seizure and land reform teams were peasants themselves, 
having gained the notice of Party cadres by their enthusiastic participation in previous campaigns in their own villages. This stood in sharp contrast to the Russian shock brigades, Komsomol brigades, and 25,000ers, where industrial workers rather than peasants comprised the majority of members. ${ }^{58}$ In the Chinese case, after receiving intensive training from the county government, rural activists would be dispatched to surrounding villages to diffuse the mobilization model. In addition to peasants, land reform team members were drawn from party and government agencies, the army, and various high schools and colleges. Factory workers were, however, notably absent. Continuing a pattern that dated back to the Peasant Movement Training Institute of the 1920s and the anti-Japanese struggle of the 1930s and 1940s, idealistic students and their teachers remained a primary focus of recruitment. ${ }^{59}$ Incorporating "intellectuals" with at least a modicum of literacy and computational skills ensured that requisite records and reports could be properly compiled and filed. Welcoming such people to the revolutionary ranks also helped win the allegiance and obedience of the educated elite.

In the early PRC, work team rosters listed a substantial number of members who hailed from relatively privileged backgrounds, even including some from landlord families deemed to be friendly to the new political order. For example, 71 percent of a team operating in Guangxi in 1952 reportedly came from upper and middle status family backgrounds: 13 percent landlords, 5 percent rich peasants, 20 percent middle peasants, 9 percent capitalists, and 24 percent petit bourgeoisie. ${ }^{60}$ In Guangdong, local teachers and students who were not formally a part of work teams assisted on the sidelines by helping to disseminate information and propaganda. ${ }^{61}$ Despite the upper class origins of many team members, the goal of the teams was to transfer local political authority into the hands of those who had previously been excluded from its exercise. Before leaving a village, land reform work teams were required to establish a poor peasants' 
association, composed mostly of resident tenant farmers and hired agricultural laborers, which would conduct the actual redistribution of land and other property. ${ }^{62}$

As outsiders to the villages where they operated, work teams were not beholden to parochial interests and were therefore positioned to push through central policies even in the face of opposition from local powerholders. But the intrinsic nature of the teams - as mobile units deployed only temporarily to any one site —also rendered their efforts vulnerable to reversal once they had departed the scene. To counteract this tendency, in late 1951 the CCP began a practice of sending down a series of unannounced follow-up (回头) work teams to ensure that the initiatives introduced by earlier teams were still being honored and enforced. Most villages in Central-South China received at least four successive rounds of land reform work teams over the next year and a half. ${ }^{63}$

Although the membership of these repeated waves of land reform work teams was reshuffled from one round to the next, the mode of operations remained basically the same and was captured in the language of a folksy new lexicon. The process involved "squatting on a point” (蹲点)—or remaining for a period of weeks or months at a single site—while practicing the "three togethers" (三同) of living, eating and working with the locals. Team members were enjoined to “strike roots” (扎根) by identifying “backbones” (骨干)—or homegrown activists— who could “speak bitterness" (诉苦) and “forge links" (串联), or connect with other villagers, to carry out the campaign. While team members themselves were outsiders whose wages and welfare benefits came from their home units, they were supposed to "squat on a point" long enough to gain the trust of local inhabitants and reach an accurate assessment of the situation. By living, eating and working alongside ordinary villagers, they would be able to cultivate indigenous activists who could be counted on to do the Party's bidding with enthusiasm. ${ }^{64}$ In 
bypassing the regular administrative hierarchy, work teams established a direct connection between the central state and grassroots society ${ }^{65}$ This approach (and the specialized vocabulary that described it) was not only standard operating procedure for the Land Reform campaign (1947-1952); the protocol remained in place through the subsequent Collectivization (1953-56) and Four Cleans (1963-1965) campaigns, and, in somewhat modified form, has most recently been employed in the New Socialist Countryside Construction and Precision Poverty Alleviation Program as well.

Marked by a common repertoire of mobilizing routines and rhetoric, the substance and style of work team operations varied nevertheless in step with changes in central policy and political climate. While coercion figured to some extent in all mass campaigns, levels of violence fluctuated. As we have seen, Land Reform was known for impassioned "speak bitterness" rituals in which victimized peasants were sought out and then coached by the work teams to condemn landlords and other "bad classes" as a prelude to fierce struggle sessions. ${ }^{66}$ The resultant hostilities frequently exceeded approved bounds. For example, a work team leader recalled of a struggle session at a village in Hunan in the winter of 1951 :

Once, when I was in Caojixi Village, I led an anti-tyrant struggle meeting. A tyrannical landlord stood on the platform to be struggled against as one after another poor peasant and hired laborer mounted the platform to speak bitterness. One extremely embittered and resentful hired laborer spoke bitterness until he began to sob. As he passed by the landlord, with a cry of "Bah!" that frightened the entire assembly, he bit off half of the landlord's right ear. Then he prepared to bite the landlord's left ear. I stopped him at once. $^{67}$

Violence was meant to be the monopoly of the militia, with neither work teams nor ordinary 
peasants authorized to take justice into their own hands, but the speak bitterness ritual created an emotionally charged atmosphere that was difficult to contain. ${ }^{68}$ Millions lost their lives in the Land Reform Campaign, some to militia firing squads and others to agitated villagers. Repeated waves of work teams dispatched to the same villages were triggered not only by counterrevolutionary reversals on behalf of local powerholders, but also by radical excesses on the part of enraged peasants.

The basic formula for work team operations remained similar from the time of Land Reform on, but subsequent campaigns for rural transformation took greater pains to prevent unsanctioned violence. The very ferocity of Land Reform helped pave the way for a more moderate version of Collectivization in China than had transpired in the Soviet Union. In Russia, the expropriation and deportation of kulaks from their native villages during collectivization was intended to eliminate the pre-revolutionary local elite, a process that in China had already occurred with Land Reform. The greater brutality and resistance to collectivization in the USSR, it has been suggested, was a product of the Soviet state's effort to achieve several ambitious objectives simultaneously: political control of the villages, economic control of agricultural production, and exploitation of the countryside for the benefit of the cities. ${ }^{69}$ In China, where Land Reform had already installed a new rural leadership structure to replace the old village elite, the subsequent Collectivization campaign was aimed at the narrower goal of controlling agricultural production. In addition to the more limited objectives of China's Collectivization campaign, the earlier violence of Land Reform and the Suppression of Counter-Revolutionaries (1950-1951) campaigns had left little doubt in the minds of most Chinese citizens that resistance to the policies of the new regime would be futile.

While Land Reform and Collectivization were intended to remake the political economy of 
the Chinese countryside, the Four Cleans Movement (四清运动) of the early to mid-1960s was directed at the seemingly more modest goal of checking administrative abuses among grassroots officials. Occurring in the immediate wake of Mao's disastrous Great Leap Forward, it was a massive effort, with major consequences, nonetheless. In the Four Cleans, over three and a half million people were dispatched to the countryside as members of work teams charged with investigating fraud, embezzlement, waste, and other malfeasance on the part of local cadres. While "squatting on a point" and carrying out the "three togethers," team members followed the Land Reform playbook of "striking roots" and identifying "backbones" capable of mobilizing their fellow villagers. House-to-house visits, small group discussions and all-village meetings were then convened for the purpose of exposing grassroots leadership improprieties. The process was often contentious, with local factions and rivals accusing one another of corrupt or abusive behavior. However, in comparison to Land Reform, the Four Cleans unfolded in a relatively restrained manner. Work team members were tasked not only with igniting mass passions against village cadres; they were also expected to "maintain 'temperature control' over the movement" (把握运动的 “火候”) so that struggle sessions remained within approved bounds. ${ }^{70}$ The rural militia was armed and available to impose order.

The comparative moderation of the Four Cleans was also due to the thorough training (sometimes lasting several months) that work team members received before being sent to the villages. As in Land Reform, a substantial portion of team members were college students and professors. In some provinces, virtually every university upperclassman participated. Their educational background qualified them to collect investigation materials, draft team reports, compile financial accounts, and edit histories of the local units to which they had been assigned. ${ }^{71}$ Commissioned at a moment when Mao Zedong was envisioning a radical overhaul of 
China's education system, the work teams were meant to provide a revolutionary pedagogy to the student participants. ${ }^{72}$

Dispatched on the heels of the deadliest famine in world history, the Four Cleans work teams performed a major service for regime stability by diverting culpability for the catastrophe away from the central leadership. In pointing the finger of blame for the Great Leap debacle at the malfeasance of grassroots cadres, work teams deflected public recrimination from the actual architects of the disaster in the higher echelons of the Party. Besides identifying local scapegoats to hold accountable for peasants' woes, the Four Cleans work teams served as a vehicle for strengthening the commitment and loyalty of team members themselves. During protracted training sessions for prospective team members, detailed disciplinary regulations, based on practices in the People's Liberation Army, were introduced. The lengthy training process also involved intensive examinations of trainees' class status, family background, political outlook, and general deportment to determine whether they were fit to serve. These investigations, which included the repeated writing of confessions and self-criticisms, resulted in prizes for trainees deemed especially praiseworthy, and punishments for those found guilty of serious disciplinary infractions. ${ }^{73}$

The close monitoring of work team members' behavior continued during their deployment. Those judged to be unusually meritorious were awarded the title of "five-good team members," and were lauded in publicly circulated bulletins. While on assignment, team members were required to attend weekly refresher training sessions in the county seat, where they learned about new central directives, listened to reports of successful work experiences in nearby locales, were reminded of disciplinary regulations, and participated in morale-boosting exercises. Work team members were also subject to unannounced investigations by inspection teams sent from the 
provincial Party Committee. The effect of all this instruction and surveillance was to increase political awareness among work team members, rendering them highly attentive to upper-level directions. ${ }^{74}$

Eliciting team members' ready compliance with regime demands constituted a significant achievement during this period of political uncertainty and potential instability following the Great Leap calamity. Intellectuals and mid-level cadres who might otherwise have been inclined to criticize the central leadership learned through their participation in Four Cleans work teams to direct their condemnation toward local officials instead. Although the stinging attacks on the alleged venality of grassroots cadres may have instilled a lasting suspicion toward local officials on the part of many ordinary people, the work teams apparently also helped to reinforce villagers' allegiance to Party Central by communicating the top leaders' concern for their plight. ${ }^{75}$

The effectiveness of work teams in carrying out a series of important campaigns in the early years of the PRC made them a favored mode of policy implementation from that period forward, especially for purposes of rural development. Although Mao himself, in the run up to the Cultural Revolution, expressed skepticism toward what he deemed to be an overreliance on Party-controlled work teams at the expense of a more direct, unmediated form of mass participation, ${ }^{76}$ post-Mao leaders would return to work teams again and again: Deng Xiaoping and Jiang Zemin in the One-Child Family Campaign, Hu Jintao and Wen Jiabao in the New Socialist Countryside Construction, and Xi Jinping in the Precision Poverty Alleviation Program, to name only a few of the more prominent instances. Work teams have also been deployed repeatedly to popularize Party ideology, promote public health and environmental protection, pacify protests, provide disaster relief, and much more. 


\section{THE PRC AND THE USSR PATTERNS COMPARED}

Having sprung from Russian revolutionary roots, Chinese work teams resembled their Soviet forerunners in many respects. In both countries, mobile units performed a critical role in communicating and implementing Communist Party policies in remote regions of the countryside both before and after the consolidation of state power. Yet the Chinese pattern also diverged in significant ways from Soviet precursors and counterparts, especially after the establishment of the two Communist states.

While the early PRC work teams were undoubtedly modeled on the grain requisition brigades deployed in the Soviet Union in its civil war and collectivization periods, the Chinese and Soviet variants differed in terms of composition, discipline, and effectiveness. In the Russian case, food detachments were urban in origin and membership, comprised largely of industrial workers. In the months immediately following the October Revolution, urban factories sent plenipotentiaries and small brigades of workers into the villages to collect grain for fellow employees. In May 1918, Lenin urged the workers of Petrograd to gather grain from the countryside, causing food detachments to be formed on a massive scale. Over the next three years, some 250,000 urban residents, half of whom were factory workers, participated in grain seizures. In a "literal attempt to install the dictatorship of the proletariat in the countryside," the plenipotentiaries, who were often industrial workers, were authorized to override local government institutions to implement the requisitioning policy. ${ }^{77}$ They seized grain from former poor peasant associations which "resented the intervention of outsiders in their affairs." The hostility of the peasants toward these urban-based brigades, according to a historian of the period, rendered the whole effort a "dismal failure.",78

Despite this unhappy experience, when Stalin launched his collectivization campaign a 
decade later, the Civil War grain requisition effort was drawn upon as a template for the intervention of outside groups in the countryside. ${ }^{79} \mathrm{R}$. W. Davies observes, "collectivization was to be accomplished by a massive incursion into the countryside of plenipotentiaries and brigades. ${ }^{" 80}$ Each level of the party and government hierarchy unleashed a "plenipotentiary blitzkrieg" on the level just below it, with collectivization emissaries racing "from village to village, to enumerate, implement, and enforce policy." ${ }^{81}$ As Lynne Viola describes the brutal process, "brigades of collectivizers with plenipotentiary powers toured the countryside, stopping briefly in villages where, often with gun in hand, they forced peasants under threat of dekulakization, to sign up to join the collective farm. ${ }^{, 82}$ Similarly, Sheila Fitzpatrick writes of the collectivization drive, "the campaign was characterized by vast 'mobilizations' of urban Communists, Komsomols, workers and students.... From the peasants' point of view, they were 'outsiders' to the nth degree. Some of them were on serious, long-term missions, like the '25,000-ers' - worker volunteers from major industrial plants.... Others were evidently pure troublemakers, the young 'Komsomol hooligan' types, out looking for some action (which usually involved drinking and attacking the church). ${ }^{, 83}$ Grain seizures and liquidation of (rich peasant) kulaks were conducted callously by outside emissaries acting with scant regard for local conditions. Enjoying de facto plenipotentiary powers, the mobile units confronted and criticized grassroots officials, whom they viewed as crude and corrupt. ${ }^{84}$ The results could be catastrophic: In January 1930, for example, "a brigade comprised of eleven people that arrived in Anna Raion literally terrorized the population... ${ }^{85}$ In response, Russian peasants at times took the law into their own hands, murdering the urban outsiders who attempted to force them into collective farming. ${ }^{86}$

This is not to say that the Soviet Union made no efforts to improve the plight of the rural 
poor. In response to the famine of 1921-1922, for example, factories and military garrisons in Moscow temporarily "adopted" impoverished villages in a sponsorship practice known as shefstvo. In 1923, Lenin advocated the creation of permanent "shefstvo societies" composed of urban workers. These were intended as paternalistic ventures in which "advanced" factory workers were expected to provide both economic and cultural assistance to "backward" peasants. ${ }^{87}$

In China, too, Land Reform and Collectivization work team members typically included a number of urbanites (Party cadres, entrepreneurs, intellectuals and so on), but the majority were peasant activists and grassroots cadres. Moreover, almost never did rural work teams include factory workers. In this respect, the Chinese model differed markedly from the Soviet Union's use of plenipotentiaries, 25,000ers, shock brigades, and the like, all of which were heavily proletarian in composition. While the Soviet pattern was promoted by Lenin and Stalin as a politically correct expression of the "dictatorship of the proletariat," the Maoist variant was designed to be more attentive to rural sensibilities. In China, the goal of ad hoc rural governance was not to bend the "benighted" peasantry to the will of the "progressive" proletariat, but rather to win over the most "oppressed" among the peasantry so that they would be inspired to assume an active part in fulfilling the Communist Party's goals. To accomplish this would require that mobile units spend a significant amount of time in rural villages, investigating local conditions and identifying local activists, so that they could transfer power to a new leadership stratum of poor peasants and agricultural laborers. Three decades of revolutionary experience in the Chinese countryside had taught Mao and his comrades the value of enlisting villagers themselves as protagonists in furthering the Party's agenda.

In the Soviet Union, the central role of the secret police (OGPU) in encouraging and 
orchestrating grain confiscation and dekulakization further contributed to peasants' antagonism toward the urban-based party-state. In 1929, the Central Committee ordered the OGPU to intensify repression in all grain-producing regions. ${ }^{88}$ In February 1930, "operational troikas" were created under the direction of the OGPU to carry out the displacement of kulaks. The troikas, which reported to OGPU plenipotentiary representative offices at various levels, played a key part in building the Soviet police state. By 1931, Stalin and the OGPU were in control of a vast economic and penal empire, based on the labor of deported kulaks and serving as the foundation of the gulag. ${ }^{89}$ The outcome of collectivization was a deep alienation of the Russian peasantry from the Soviet state. E. H. Carr summarizes the legacy of the campaign: "The peasant saw the emissaries from Moscow as invaders who had come ... to destroy his cherished way of life.... Force was on the side of the authorities, and was brutally and ruthlessly applied. The peasant - and not only the kulak - was the victim of what looked like naked aggression. What was planned as a great achievement ended in one of the great tragedies that left a stain on Soviet history." $" 90$

Under Stalin's Great Terror, plenipotentiaries and troikas throughout the 1930s presided over the purges of countless innocent people both inside and outside the Party. ${ }^{91}$ Endemic problems of drunken, dissolute behavior on the part of unrestrained emissaries generated a mountain of grievances and complaints from Russian peasants and local officials alike. Peasants resented the tyrannical behavior of the autocratic urban envoys, which often included arbitrary imprisonments, beatings, and other forms of corporal punishment, while grassroots cadres chafed under the outsiders' ability to short-circuit regular government channels in favor of extrabureaucratic intervention. ${ }^{92}$

After Stalin's death, this "blitzkrieg" style of governance was roundly condemned as 
corrosive of orderly Party and government procedures. Ad hoc emissaries were accordingly deployed less often and invested with less discretionary power. A government report in 1953 noted that "Raikoms are ever more frequently refraining from sending so-called plenipotentiaries to the kolkhozes for current economic and political campaigns. When the raion Party aktiv goes to a kolkhoz, it acts through the primary organization. Under the constant attention of the raikom the primary Party organizations exert more influence on the course of all business than do the various kinds of plenipotentiaries. ${ }^{, 93}$ Khrushchev and his successors were inclined to replace this revolutionary vestige with a more routinized mode of bureaucratic administration.

In China, however, the practice of work teams continued to occupy a valued place in the central leadership's governance tool box. The massive national Land Reform campaign of 19471953, which occurred just as the Soviet Union was dispensing with the use of ad hoc mobile units, saw the deployment of work teams in the PRC attain a heightened level of sophistication and standardization that has persisted to the present. Chinese Land Reform teams remained in villages longer and forged closer connections to the rural populace than Soviet plenipotentiaries. Having been carefully instructed by upper levels of government to practice the "three togethers" of eating, living and working with the local villagers, work teams enjoyed greater success than their Soviet counterparts in enlisting the active engagement of ordinary peasants in carrying out the Party's ambitious plans for rural transformation.

The popular passions unleashed by work teams over the course of China's Land Reform resulted in an explosion of violence that sometimes spiraled out of control, however. In subsequent campaigns, therefore, work team members received training not only in how to stimulate mass participation, but also in how to prevent massive bloodshed. Having convincingly established its authority in the countryside via Land Reform, the Party henceforth endorsed a 
more restrained version of mass mobilization (evident in Collectivization and the Four Cleans) designed to consolidate the new political order.

Western social scientists have generally agreed that China's version of collectivization was far less deadly and destructive than had been true for the Soviet Union and Eastern Europe. Summing up this consensus, Mark Selden observes that "China's collectivization was achieved in the absence of both the violence and the economic collapse that characterized Soviet collectivization. ${ }^{94}$ Thomas Bernstein attributes this difference to the better relations that work teams cultivated with both peasants and grassroots officials. ${ }^{95}$ Although recent scholarship by Chinese historians, based on archival sources, has documented greater resistance to collectivization than previously recognized, the contrast conventionally drawn with the Soviet Union remains valid. ${ }^{96}$ While collectivization in China was conducted by mobile units that superficially resembled the workers' brigades, plenipotentiaries, and troikas of the USSR, in fact Chinese work teams operated quite differently. Among other things, the greater reliance on idealistic and carefully trained students and professors (as opposed to urban factory workers), in combination with rural elements, rendered the Chinese version more responsive and restrained than its Soviet prototype.

China's comparative success in controlling its mobile units helps to explain the PRC's continued reliance on this revolutionary legacy. Instead of eschewing the ad hoc deployment of work teams as a threat to political institutionalization and consolidation, Mao and his successors chose to incorporate the practice as an integral (if intermittent) feature of PRC governance. In the early 1950 s, at the very time that the USSR was dismantling its longstanding pattern of dispatching various types of mobile units from city to countryside, the PRC expanded and standardized its own use of work teams. A decade later, when the massive assignment of Four 
Cleans work teams helped shield Mao's regime from the Great Leap disaster, the political payoff from this approach was proven.

\section{CONCLUSION}

The contrasting fate of mobile units in the PRC and USSR reflects the very different place of rural mobilization in their revolutionary paths to power. Unlike Lenin's October Revolution, which was swift and urban, Mao's tortuous thirty-year revolution was won in the countryside. Over the course of that protracted struggle, which took the CCP across much of China's remote hinterland, Mao and his comrades learned to refashion Russian revolutionary techniques into methods better suited to a far-flung agrarian context. Among the most important achievements in this process was the adoption and adaptation of work teams as an instrument of grassroots mobilization and policy implementation.

The PRC's continued reliance on ad hoc work teams after the consolidation of revolutionary victory has contributed to its remarkable capacity to effect dramatic change in even the most distant reaches of the countryside. Whereas Stalin's successors succumbed to an increasingly routinized and reified party-state apparatus, Chinese leaders retained and refined this cornerstone of campaign-style governance so as to reserve the option for intermittent yet influential grassroots interventions. ${ }^{97}$

The collapse of European Communist regimes is often attributed to their dysfunctional political institutions. ${ }^{98}$ But the formal institutions of the PRC—Communist Party, Central Committee, Politburo, Nomenklatura, and so on—are cut from the same cloth as the former Soviet and East European pattern. Yet the PRC has now outlasted the fall of the Soviet Union by nearly three decades, and at present shows no obvious signs of following in the ignominious footsteps of its "Big Brother." Furthermore, the Chinese party-state has managed not only to 
avoid collapse, but to actually work - engineering an impressive series of developmental successes from public health and rural education in Mao's day to the fastest sustained economic growth and poverty reduction in world history in the post-Mao era. To be sure, the regular partystate administration played an important role in these outcomes. The continuing contribution of work teams was also significant, however, serving as a periodic but powerful counterweight against official inertia and an impetus for consequential grassroots citizen involvement.

The prevailing image of work teams in the Chinese countryside stands in sharp contrast to that of mobile units in the former Soviet Union. For many Chinese citizens, outside work teams are regarded as a welcome means of disciplining grassroots cadres and distributing valuable state resources. The relatively favorable impression is a result of of the CCP's sustained efforts to render this ad hoc mode of central-local governance compatible with grassroots demands. At the end of the twentieth century, when the use of work teams for anti-corruption campaigns in the Chinese countryside had temporarily subsided (soon to be revived under Xi Jinping), villagers were reported to "yearn for agents of higher levels appearing in their villages to clean things up. ${ }^{99}$

This is not to suggest that work teams have been a consistent force for positive or popular change. Sometimes their draconian methods, on full display in the One Child Family Campaign for example, have elicited harsh criticisms and even policy reversals from the central leadership. ${ }^{100}$ Not surprisingly, local officials in the PRC, like their counterparts in the USSR, are apt to complain about the disruption that outside work teams create for administrative procedures and routines. But it is precisely the capacity of work teams to check the independent authority of lower-level cadres by means of mass mobilization that renders this governance mechanism conducive to the swift implementation of state initiatives. 
Political scientist Robert Putnam in his studies of Italy and the United States argues that what "makes democracy work" are the civic associations that engage ordinary Italians and Americans in public life. ${ }^{101}$ Democracies perform best, Putnam contends, when citizens are themselves actively and collectively involved in political affairs; a robust civil society contributes both to state capacity and to good governance. In the case of China, operating under a radically different type of political regime, work teams would seem to play something of an analogous role- “making Communism work" not through strengthening civil society but by enlisting ordinary people collectively and collaboratively in the Party's ambitious agenda.

Work teams facilitate state capacity, but whether they contribute to good governance depends in large measure on the wisdom of the policies they are called upon to promote. On the one hand, for example, work teams helped rid China in the 1950s of the devastating scourges of smallpox and schistosomiasis; on the other hand, in the 1980s and 1990s they were used to push a demographically disastrous birth control program. Today they are deployed both to enforce food safety and environmental protection standards and to impose ideological conformity on the universities. But regardless of the positives or negatives of the various initiatives they are asked to advance, work teams can deliver a significant political dividend in terms of central-local relations. As a complement and counterweight to the normal bureaucratic chain of command, prone as it is to inertia and corruption, this alternative mode of governance offers an immediate channel of state-society communication.

The costs of this extra-bureaucratic approach can also be considerable, however. If not carefully instructed and overseen by the agencies that dispatch them, work teams may generate chaotic confusion at the grassroots. This was the situation at the start of the Cultural Revolution, when work teams sent in haste to schools and factories in the spring of 1966 triggered intense 
factionalism on the ground. ${ }^{102}$ Mao's decision soon thereafter to withdraw the work teams in favor of unmediated mass activism unleashed a torrent of violence that even he could not abide for long. In the summer of 1968 he authorized Mao Zedong Thought Propaganda Teams (work teams by another name), operating under the supervision of the military, to reimpose order. ${ }^{103}$ Unlike mobile units in the Soviet Union, China's work teams did not perish with the passing of the revolutionary generation. Rather, post-Mao leaders have returned repeatedly to this protean practice for various pressing purposes, for example, delivering disaster relief during the Wenchuan earthquake of 2008 and restoring order during the Wukan protests of 2011. The use of state-directed citizen engagement as an antidote for sclerotic administrative procedures has served not only as a useful instrument of crisis response; it has also helped mitigate the institutional erosion and implosion that undid the Soviet Union and its client states across Eastern Europe. As a mutable mechanism that can be recalibrated to meet the exigencies of different situations, work teams enjoy an operational flexibility and versatility that eludes more formally constituted institutions of governance. While the efficacy and endurance of the past century of Chinese Communism is undoubtedly due to many complex and contingent factors, the continuing contributions of work teams rank high among them. 
Abstract: Among various grassroots governance practices adopted by the Chinese Communist Party (CCP), few have proven more adaptive and effective than the deployment of work teams -ad hoc units appointed and directed by higher-level Party and government organs and dispatched for a limited time to carry out a specific mission by means of mass mobilization. Yet, perhaps because work teams straddle the boundary between formal and informal institutions, they have received scant analytical attention. While work teams figure prominently in narrative accounts of the major campaigns of Mao's China, their origins, operations and contemporary implications have yet to be fully explored. This article traces the roots of Chinese work teams to Russian revolutionary precedents, including plenipotentiaries, shock brigades, 25,000ers and the like, but argues that the CCP's adoption and enhancement of this practice involved creative adaptation over a sustained period of revolutionary and post-revolutionary experimentation. Sinicized work teams were not only a key factor in securing the victory of the Chinese Communist revolution and conducting Maoist mass campaigns such as Land Reform, Collectivization and the Four Cleans; they continue to play an important role in the development and control of grassroots Chinese society even today. As a flexible means of spanning the center-periphery divide and combatting bureaucratic inertia, Chinese work teams, in contrast to their Soviet precursors, contribute to the resilience of the Communist party-state.

Key words: work teams, plenipotentiaries, Russian Revolution, Chinese Revolution, Mao Zedong, Lenin, Stalin, central-local linkages, mass mobilization, authoritarian resilience 


\footnotetext{
${ }^{1}$ Benjamin A. Elman, Civil Examinations and Meritocracy in Late Imperial China
} (Princeton: Princeton University Press, 2013).

${ }^{2}$ Kung-chuan Hsiao, Rural China: Imperial Control in the Nineteenth Century (Seattle: University of Washington Press, 1960), 184-205; Zhengyuan Fu, Autocratic Tradition and Chinese Politics (New York: Cambridge University Press, 1993), 101-2.

${ }^{3}$ Li Konghuai (李孔怀), A History of Ancient China's Administrative System (中国古代行政 制度史) (Shanghai: Fudan University Press, 2006).

${ }^{4}$ Hung-mao Tien, Government and Politics in Kuomintang China (Stanford: Stanford University Press, 1972); Lloyd Eastman, The Abortive Revolution: China under Nationalist Rule (Cambridge: Harvard University Press, 1974).

${ }^{5}$ Elizabeth J. Perry, Shanghai on Strike: The Politics of Chinese Labor (Stanford: Stanford University Press, 1993); S. A. Smith, Like Cattle and Horses: Nationalism and Labor in Shanghai, 1895-1927 (Durham: Duke University Press, 2002).

\footnotetext{
${ }^{6}$ Victoria Bonnell, Roots of Rebellion: Workers' Politics and Organizations in St. Petersburg
} and Moscow (Berkeley: University of California Press, 1983); David M. Mandel, The Petrograd Workers and the Fall of the Old Regime (New York: St. Martin’s Press, 1983): S. A. Smith, Red Petrograd: Revolution in the Factories, 1917-1918 (Cambridge: Cambridge University Press, 1983); Diane Koenker, Moscow Workers and the 1917 Revolution (Princeton: Princeton University Press, 1981); Lynne Viola, V. P. Danilov, N. A. Ivnitskii, and Denis Kozlov, eds., The War against the Peasantry: The Tragedy of the Soviet Countryside (New Haven: Yale University Press, 2005); Lynne Viola, Peasant Rebels under Stalin: Collectivization and the Culture of Peasant Resistance (New York: Oxford University Press, 1996). 
${ }^{7}$ Benjamin I. Schwartz, Chinese Communism and the Rise of Mao (Cambridge: Harvard University Press, 1951); Lucien Bianco, Origins of the Chinese Revolution (Stanford: Stanford University Press, 1974).

${ }^{8}$ Elizabeth J. Perry, "From Mass Campaigns to Managed Campaigns: “Constructing a New Socialist Countryside," in Sebastian Heilmann and Elizabeth J. Perry, eds., Mao's Invisible Hand: The Political Foundations of Adaptive Governance in China (Cambridge: Harvard University Press), 30-61.

${ }^{9}$ Selected Materials on the Guangzhou Peasant Movement Training Institute (广州农民运动 讲习所资料选编) (Beijing: People's Press, 1987), 35-40.

${ }^{10}$ Ibid., 27.

${ }^{11}$ Hsin-pao Chang, Commissioner Lin and the Opium War (New York: Norton, 1970).

${ }^{12}$ Dan N. Jacobs, Borodin: Stalin's Man in China (Cambridge: Harvard University Press, 1981), 152-54. Allen S. Whiting has argued that "perhaps more than any other single person [Borodin] was responsible for the successes of the Chinese revolution from 1924 to 1927"; Soviet Policies in China, 1917-1924 (New York: Columbia University Press, 1954), 245. At the same time, moreover, hundreds of left-leaning Chinese were being trained at the Sun Yat-sen University of the Toilers of the East in Moscow. Alexander Pantsov, The Bolsheviks and the Chinese Revolution, 1919-1927 (Richmond: Curzon Press, 2000), 164-69. In short, there were multiple conduits for the transmission of Soviet mobilization techniques to China. See also C. Martin Wilbur and Julie Lien-ying How, Missionaries of Revolution: Soviet Advisers and Nationalist China, 1920-1927 (Cambridge: Harvard University Press, 1989).

${ }^{13}$ A Chinese translation of Gogol's comedy was first published by the Commercial Press in Shanghai in 1921; in subsequent years at least eight additional Chinese translations have 
appeared under the title of 钦差大臣.

${ }^{14}$ Christopher Read, Lenin: A Revolutionary Life (New York: Routledge), 188.

${ }^{15}$ Li Jiawei (李佳威) and Tian Yu (田聿), “Voitinsky: Clandestine Comintern Special Commissioner” (维经斯基：默默无闻的共产国际特派员), in Dang'an Chunqiu (档案春秋) (June 2011); Wang Jie (王洁), Li Dazhao's Decade in Beijing (李大钊北京十年) (Beijing: Central Translation Press, 2015).

${ }^{16}$ Yu Jie (余杰), Borodin: Matador Waving a Red Cloth (鲍罗廷：挥舞红布的斗牛士), http://www.chinesepen.org/blog/archives/83397 (accessed 4 Apr. 2017).

${ }^{17}$ Liu Baodong (刘宝东), The Start of a Revolutionary Road with Chinese Characteristics (中 国特色革命道路的开辟) (26 May 2011)， http://dangjian.people.com.cn/GB/136058/221814/14750481.html (accessed 27 Feb. 2018).

${ }^{18}$ Wang Qisheng (王奇生), “Revolutionary Mobilization of the Underclass: Mechanisms of Peasant Mobilization and Participation in the CCP's Early Period" (革命的底层动员: 中共早 期农民运动的动员、参与机制), in Wang Jianlang (王建朗) and Huang Kewu (黄克武), eds., New Histories of Modern China across the Straits (两岸新编中国近代史) (Beijing: Social Science Documents Press, 2016), 268.

${ }^{19}$ In 1924-1925, the CCP-sponsored Guangdong Peasant Association began to organize "tenperson groups" (十人团) among its most politically conscious “backbone" members to incite tax and rent resistance across the province. Also known as the “poor people's party” (贫人党), these groups were evidently influenced by the Triad secret society tradition that was deeply entrenched in this part of China. In addition to using clandestine codes and passwords, members went through an initiation ritual of drinking chicken blood mixed with alcohol to signify their loyalty 
to the proletarian cause. See Ye Zuoneng (叶佐能), Peng Pai and the Hailufeng Base Area (彭 看与海陆丰根据地) (Beijing: Central Party School Press, 2011), 99-101; Liu Linsong (刘林松) and Cai Luo (蔡洛), eds., Remembering Peng Pai (回忆彭湃) (Beijing: Beijing People’s Press, 1992), 160; Haifeng County Party Committee History Office, ed., A Brief History of the Hailufeng Revolutionary Base Area (海陆丰革命根据地简史) (Beijing: Chinese Communist Party History Press, 2011), 11.

${ }^{20}$ Peter Kenez, The Birth of the Propaganda State: Soviet Methods of Mass Mobilization, 1917-1929 (Cambridge: Cambridge University Press, 1985); Richard Pipes, Russia Under the Bolshevik Regime (New York: Vintage, 1995).

${ }^{21}$ Selected Materials on the Guangzhou Peasant Movement Training Institute, 56.

${ }^{22}$ Lynne Viola, The Best Sons of the Fatherland: Workers in the Vanguard of Soviet Collectivization (New York: Oxford University Press, 1987), 11-12.

23 “'Spreading Fire—Remembering Comrade Dong Biwu's Early Revolutionary Activities in Hong'an” (播火人一缅怀董必武同志早期在红安的革命活动), http://www.china.com.cn/aboutchina/zhuanti/zgzyldz/2007-09/17/content 8898268.htm (accessed 17 Sept. 2007), Historical materials on CCP Organizations in Hubei's Huang'gang district (中共湖北省黄冈地区组织史资料), vol. 1 (1992), 9. [CHECK I'VE NOT MISREAD THAT. THAT IS, IS THE "Spreading Fire" ARTICLE IN THE "Historical Materials"? AND YOU ACCESSED IT ON THIS WEBSITE ON 17 SEPT.?] Yes, that is correct

${ }^{24}$ Wilbur and How, Missionaries of Revolution, 749.

${ }^{25}$ Ibid.

${ }^{26}$ Antonio Gramsci, Selections from the Prison Notebooks (New York: International Publishers, 1971), 10. 
${ }^{27}$ Liu Jinhai (刘金海), “Work Teams: A Special Organization and Pattern for Rural Work in Contemporary China” (工作队: 当代中国农村工作的特殊组织及形式), Studies in CCP Party History (中共党史研究) 12 (2012): [GIVE FULL PAGE RANGE], 50-59. On Mao's status as special commissioner in the Autumn Harvest Uprising, see A History of the Autumn Harvest Uprising on the Hunan-Jiangxi Border (湘赣边界秋收起义史) (Nanchang: Jiangxi People's Press, 2003), 44.[THE LATTER HAS NO AUTHOR?] Author is Pingxiang City Communist Party History Association

${ }^{28}$ Brian James DeMare, Mao's Cultural Army: Drama Troupes in China's Rural Revolution (New York: Cambridge University Press, 2015), 28-29.

${ }^{29}$ Wang Jianying (王健英), Annals in the Organizational History of the Chinese Communist Party (中国共产党组织史大事记实), vol. 2 (Guangzhou: Guangdong People’s Press, 2003), 510.

${ }^{30}$ CCP Central Organization Department, CCP Central Party History Office, Central Archives, eds., Historical Materials on the Organization of the Chinese Communist Party (中国 共产党组织史资料), (Beijing: CCP Party History Press, 2000), vol. 13, 401-4.

${ }^{31}$ Zhang Qi'an (张启安), Cradle of the Republic: The Chinese Soviet Republic (共和国摇 篮：中华苏维埃共和国 ) (Xi'an: Shaanxi People’s Press, 2003), 455.

${ }^{32}$ E. A. Rees, State Control in Soviet Russia: The Rise and Fall of the Workers' and Peasants’ Inspectorate, 1920-1934 (London: Palgrave Macmillan, 1987), 147-50.

${ }^{33}$ Other agencies deployed teams of “communications officers” (通讯员队伍) and “light cavalry brigades" (轻骑队), composed of young volunteers, who also reported to the Soviet government on infractions by official associations, enterprises and cooperatives. But these 
appear to have been more of a bottom-up form of mass surveillance. Zhang, Cradle of the Republic, 458-60.

${ }^{34}$ Ilpyong J. Kim, The Politics of Chinese Communism: Kiangsi under the Soviets (Berkeley: University of California Press, 1973), 164.

${ }^{35}$ Yu Boliu (余伯流) and Ling Buji (凌步机), The Historical Experience of Chinese Communist Party Governance in the Soviet Areas (中国共产党苏区执政的历史经验) (Beijing: Chinese Communist Party History Press, 2010), 280.

${ }^{36} \mathrm{Kim}$, Politics of Chinese Communism, 80.

${ }^{37}$ Li Xiaosan (李小三), A Brief History of the Central Revolutionary Base Area (中央革命根 据地简史) (Nanchang: Jiangxi People's Press, 2009), 204; Yu Boliu and Ling Buji, Historical Experience, 273-74.

${ }^{38}$ In the USSR, abolition of the Workers' and Peasants' Inspectorate in February 1934 "cleared the ground for a more centralized, less accountable, more implacable system of control." Rees, State Control, 224.

${ }^{39}$ Kim, Politics of Chinese Communism, 21.

${ }^{40}$ Mao Zedong, “A Preliminary Summing Up of the Land Investigation Movement” (August 1933), in Stuart R. Schram, ed., Mao's Road to Power: Revolutionary Writings, 1912-1949 (Armonk, NY: M.E. Sharpe, 1992), vol. 4, 505.[WE NEED MORE REFERENCE INFO FOR MAO 'S ROAD TO POWER]

41 “Mao Zedong's Support for the 1933 Elimination of Corruption in the Soviet District: Daring to Operate, Our Hands are not Soft” (毛泽东支持 1933 年苏区肃贪: 敢开刀我绝不手 软), in Hunan Daily (湖南日报) (28 Apr. 2014), http://www.chinanews.com/mil/2014/0428/6112544.shtml (accessed 22 Dec. 2018). 
${ }^{42}$ Selected Collection of CCP Central Documents (中共中央文件选集), vol. 11 (1 Aug. 1937), 316.

${ }^{43}$ CCP Central Documents, vol. 12 (3 Mar. 1939), 36.

${ }^{44}$ CCP Central Documents, vol. 14 (2 July 1943), 58; vol. 14 (31 Jan. 1944), 161; vol. 14 (11 Apr. 1944), 219; vol. 14 (15 Dec. 1944), 417.

${ }^{45}$ CCP Central Documents, vol. 15 (16 June 1945), 210-11.

${ }^{46}$ Yung-fa Chen, Making Revolution: The Communist Movement in Eastern and Central China, 1937-1945 (Berkeley: University of California Press, 1986), 165.

${ }^{47}$ Ibid., 166.

${ }^{48}$ Ibid., 168-70.

${ }^{49}$ Gao Hua (高华), How the Red Sun Rose: Origins and Outcomes of the Yan'an Rectification Movement (红太阳是怎样升起的: 延安整风运动的来龙去脉) (Hong Kong: Chinese University Press, 2000).

${ }^{50}$ Mark Selden, “The Yenan Legacy: The Mass Line,” in A. Doak Barnett, ed., Chinese Communist Politics in Action (Seattle: University of Washington Press, 1969), 122-23. This practice outlived the Rectification Movement. During the Civil War, the Northeast Bureau of the CCP called for recruiting young intellectuals to organize "big work teams" to mobilize the masses. CCP Central Documents, vol. 16 (28 Apr. 1946), 141.

${ }^{51}$ Chen, Making Revolution, 170-91.

${ }^{52}$ Speak Bitterness, Wreak Revenge (诉苦复仇), edited by the Political Department of the Jinchaji Military Region (Dec. 1947), 46.

${ }^{53}$ Sun Feiyu, Social Suffering and Political Confession: Suku in Modern China (Singapore: World Scientific Publishing, 2013); Guo Wu, "Speaking Bitterness: Political Education in Land 
Reform and Military Training under the CCP, 1947-51," Chinese Historical Review 21 (2014): $3-23$.

${ }^{54}$ Mao Zedong, “Convert the Army into a Work Team” (把军队变成工作队), Selected Works of Mao Zedong (毛泽东选集), vol. 4 (Beijing: People’s Press, 1991), 1405.

${ }^{55}$ Liu Jinhai, "Work Teams"; CCP Central Documents, vol. 18 (8 Feb. 1948), 125; Ye Ding (叶顶), Southbound, Southbound (南下南下) (Wuhan: Wuhan Press, 2010); Li Qing (丽晴), Southbound Cadres (南下干部) (Beijing: People's Liberation Army Arts and Culture Press, 2008).

${ }^{56}$ CCP Central Documents, vol. 18 (19 July 1949), 390.

${ }^{57}$ CCP Central Documents, vol. 18 (21 Mar. 1949), 188.

${ }^{58}$ Viola, Best Sons.

${ }^{59}$ Edwin E. Moise, Land Reform in China and North Vietnam: Consolidating the Revolution at the Village Level (Chapel Hill: University of North Carolina Press, 1983), 112.

${ }^{60}$ Ibid., 113.

${ }^{61}$ Ibid., 123.

${ }^{62}$ Ibid., $131-35$.

${ }^{63}$ Ibib., 144.

${ }^{64}$ Zhang Yinghong (张英洪), “Land Reform: Revolutionary Dictatorship and Violent Redistribution-The Case of Xupu County, Hunan” (土改: 革命专政和暴力再分配一以湖南溆 浦县为例), Modern China Studies 3 (2008): article \#10. [: INCLUSIVE PAGE NUMBERS, UNLESS THIS IS ALL THAT IS IN no. 3] It is an electronic journal, without page numbers. ${ }^{65}$ Li Lifeng (李里峰), “Work Teams: A Type of Irregular Operational Mechanism of State 
Power-A Historical Investigation Centered on the Land Reform Movement in North China" (工 作队：一种国家权力的非常规运作机制一以华北土改运动为中心的历史考查), in Jiangsu Social Science (江苏社会科学) 3 (2010): 207-14.

${ }^{66}$ William Hinton, Fanshen: A Documentary of Revolution in a Chinese Village (New York: Monthly Review Press, 1966).

${ }^{67}$ Zhang Yinghong, "Land Reform."

${ }^{68}$ Elizabeth J. Perry, "Moving the Masses: Emotion Work in the Chinese Revolution," Mobilization 7, 2 (2002): 111-28.

${ }^{69}$ Thomas P. Bernstein, "Leadership and Mass Mobilization in the Soviet and Chinese Collectivisation Campaigns of 1929-30 and 1955-56: A Comparison," China Quarterly 31 (July-Sept. 1967): 1-47. [WE NEED THE FULL PAGE RANGE OF JOURNAL ARTICLES],

${ }^{70}$ Wang Haiguang (王海光), “A Study of 'Peach Garden Model’—From the Perspective of Popular History” (“桃园经验’ 研究一从民众史的视角考查), in The Fifth Research Workshop on Contemporary Chinese History (第五届中国当代史研究工作坊) (Dec. 2016). $21 \mathrm{ff}$.

${ }^{71}$ Liu Yanwen (刘彦文), A Study of the Working Mechanism of Four Cleans Work Teams (四 清工作队工作机制研究) (MA thesis, Renmin University, 2009), 22, 32.

${ }^{72}$ See Mao's talks on education in Stuart R. Schram, ed., Chairman Mao Talks to the People, 1956-1971 (New York: Pantheon).

${ }^{73}$ Liu Yanwen, Study of the Working Mechanism, 48-56.

${ }^{74}$ Ibid., 57-69.

${ }^{75}$ Ibid., 76.

${ }^{76}$ Mao Zedong, “A Talk about the Four Cleans Movement” (关于四清运动的一次讲 
话 ) (3 Jan. 1965), in Wuhan, ed., Long Live Mao Zedong Thought (毛泽东思想万岁) (1968)

Vol. 5, doc. 140 (p. 209), https://www.marxists.org/chinese/maozedong/1968/ (accessed 22 Dec. 2018).

${ }^{77}$ Viola, Best Sons, 11-14.

${ }^{78}$ Lynne Viola, Peasant Rebels under Stalin: Collectivization and the Culture of Peasant Resistance (New York: Oxford University Press, 1996), 16.

${ }^{79}$ Viola, Best Sons, 16.

${ }^{80}$ R. W. Davies, The Industrialization of Soviet Russia: The Socialist Offensive (New York:

Palgrave, 1989), 208.

${ }^{81}$ Viola, Best Sons, 77.

${ }^{82}$ Viola, Peasant Rebels, 28.

${ }^{83}$ Sheila Fitzpatrick, Stalin's Peasants: Resistance and Survival in the Russian Village after Collectivization (New York: Oxford University Press, 1996), 50.

${ }^{84}$ Viola, Best Sons, 147.

${ }^{85}$ Viola et al, War against the Peasantry, 217.

${ }^{86}$ Gail Kligman and Katherine Verdery, Peasants under Siege: The Collectivization of Romanian Agriculture, 1949-1962 (Princeton: Princeton University Press, 2011), 75.

${ }^{87}$ William J. Chase, Workers, Society and the Soviet State: Labor and Life in Moscow, 19181929 (Urbana: University of Illinois Press, 1990), 301-2.

${ }^{88}$ Viola, et.al., War against the Peasantry, 120.

${ }^{89}$ Ibid., 242, 326, 339.

${ }^{90}$ E. H. Carr, The Russian Revolution from Lenin to Stalin, 1917-1929 (London, 1979), 162.

${ }^{91}$ Roy Aleksandrovich Medvedev, Let History Judge: The Origins and Consequences of 
Stalinism (New York: Columbia University Press, 1989), 612.

92 J. Hughes, Stalinism in a Russian Province: Collectivization and Dekulakization in Siberia

(New York: Palgrave, 1996), 110, 128; Robert F. Miller, One Thousand Tractors (Cambridge:

Harvard University Press, 1970), 204.

${ }^{93}$ Quoted in Miller, One Thousand Tractors, 205.

${ }^{94}$ Mark Selden, The Political Economy of Chinese Development (Armonk, NY: M. E. Sharpe, 1993), 98. Similarly, Vivienne Shue notes, "If we contrast the Chinese experience of socialist transformation with the more bloody and debilitating collectivizations in the USSR and elsewhere, we are struck with Chinese accomplishments.... China's collectivization was to be accomplished with amazing speed and with little violence"; Peasant China in Transition: The Dynamics of Development toward Socialism, 1949-1956 (Berkeley: University of California Press, 1980), 2, 285.

${ }^{95}$ Bernstein, "Leadership and Mass Mobilization,” 32.

${ }^{96}$ See, for example, Luo Pinghan (罗平汉), A History of the Collectivization Campaign (农业 合作化运动史) (Fuzhou: Fujian People's Press, 2004); and Li Ruojian (李若建), Between Illusion and Reality: A Study of Rumors in Mainland China in the 1950s (虚实之间: 20 世纪 50 年代中国大陆谣言研究) (Beijing: Social Science Documents Press, 2011).

${ }^{97}$ On China's adaptive governance more broadly, see Sebastian Heilmann and Elizabeth J. Perry, "Embracing Uncertainty: Guerrilla Policy Style and Adaptive Governance in China," in in S. Heilmann and E. J. Perry, eds., Mao's Invisible Hand: The Political Foundations of Adaptive Governance in China (Cambridge: Harvard University Press), 1-29.

${ }^{98}$ Valerie Bunce, Subversive Institutions: The Design and Destruction of Socialism and the State (Ithaca: Cornell University Press, 1999). 
${ }^{99}$ Kevin J. O’Brien and Lianjiang Li, "Campaign Nostalgia in the Chinese Countryside," Asian Survey 39, 3 (May/June 1999): [GIVE FULL PAGE RANGE OF ARTICLE], 375-393.

${ }^{100}$ Tyrene White cites a 1993 central document aimed at correcting the improper use of "small teams, work teams and shock brigades" to enforce birth planning. China's Longest Campaign: Birth Planning in the People’s Republic, 1949-2005 (Ithaca: Cornell University Press, 2006), 231.

${ }^{101}$ Robert D. Putnam, Making Democracy Work: Civic Traditions in Modern Italy (Princeton: Princeton University Press, 1993); Robert D. Putnam, Bowling Alone: The Collapse and Revival of American Community (New York: Simon and Schuster, 2000).

${ }^{102}$ Andrew G. Walder, Fractured Rebellion: The Beijing Red Guard Movement (Cambridge: Harvard University Press, 2012).

${ }^{103}$ Elizabeth J. Perry and Li Xun, Proletarian Power: Shanghai in the Cultural Revolution (Boulder: Westview, 1997), 30-31, 155-58; Roderick MacFarquhar and Michael Schoenhals, Mao 's Last Revolution (Cambridge: Harvard University Press, 2006), 63-65, 249-51. 